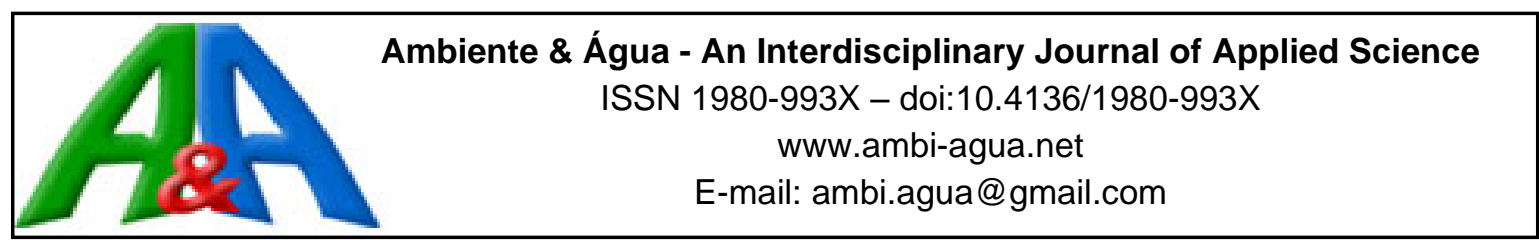

\title{
Best practice production to reduce the water footprint of dairy milk
}

\author{
ARTICLES doi:10.4136/ambi-agua.2454
}

Received: 19 Aug. 2019; Accepted: 13 Dec. 2019

\begin{abstract}
Julio Cesar Pascale Palhares ${ }^{1 *}$; ;aisla Inara Novelli ${ }^{\circledR D}$; Marcela Morelli2 ${ }^{2}$
${ }^{\mathbf{1} E m b r a p a ~ P e c u a ́ r i a ~ S u d e s t e, ~ R o d o v i a ~ W a s h i n g t o n ~ L u i z, ~ k m ~ 234, ~ C E P: ~ 13560-970, ~ S a ̃ o ~ C a r l o s, ~ S P, ~ B r a z i l ~}$ ${ }^{2}$ Departamento de Nutrição e Produção Animal. Faculdade de Medicina Veterinária e Zootecnia da Universidade de São Paulo (FMVZ/USP), Avenida Duque de Caxias Norte, n²25, CEP:13635-900, Pirassununga, SP, Brazil. E-mail: taislanovelli@hotmail.com,marcela_morelli@hotmail.com

*Corresponding author. E-mail: julio.palhares@embrapa.br
\end{abstract}

\begin{abstract}
This study evaluated the impact of diet as a mitigation action to improve the water efficiency of lactating cows. An intensive pasture dairy system was considered to calculate direct and indirect water use. Group 1 was fed with a diet containing $20 \%$ crude protein content. The crude protein content of Group 2 was adjusted according to milk production, ranging from $23 \%$ to $14.5 \%$. The total water footprints had a value of $502.4 \mathrm{~L} \mathrm{~kg}^{-1}$ fat protein corrected milk for Group 1 and $451.2 \mathrm{~L} \mathrm{~kg}^{-1}$ fat protein corrected milk for Group 2. The diet with the adjusted protein provided a reduction of $10 \%$ in the footprint value. The green water footprint was the most representative of consumption in the total value of the water footprint, $86.4 \%$ and $85.5 \%$ for Groups 1 and 2, respectively. The animals in Group 1 had a mean total drinking water consumption of $83.3 \mathrm{~L}_{\text {animal }}{ }^{-1} \mathrm{day}^{-1}$ and those of Group 2, 80.4 $\mathrm{L}_{\text {animal }}{ }^{-1}$ day $^{-1}$. This study demonstrated that high crude protein content in the diet provided a greater water footprint, therefore lower water efficiency. The proposed nutritional practice proved viable as a watermitigating action, making the ratio of liters of water per liter of milk more advantageous. The results of this study could be considered a validation of a nutritional mitigation practice to improve water efficiency and could be used as best management for the dairy supply chain.
\end{abstract}

Keywords: blue, crude protein, green, grey, nitrogen.

\section{Boa prática de produção para reduzir a pegada hídrica do leite bovino}

\section{RESUMO}

O objetivo do estudo foi avaliar o impacto do teor de proteína bruta da dieta de vacas em lactação como ação mitigadora para dar maior eficiência hídrica. Um sistema intensivo de produção de leite a pasto foi considerado para calcular os usos indiretos e diretos da água. Os animais do Grupo 1 receberam dieta contendo $20 \%$ de proteína bruta. A proteína bruta do Grupo 2 foi ajustado de acordo com a produção de leite, variando de $23 \%$ a $14.5 \%$. A pegada hídrica total teve um valor de $502,4 \mathrm{~L} \mathrm{~kg}^{-1}$ de leite corrigido para gordura e proteína para o Grupo $1 \mathrm{e}$ $451,2 \mathrm{~L} \mathrm{~kg}^{-1}$ de leite corrigido para gordura e proteína para o Grupo 2. A dieta com a proteína ajustada apresentou redução de $10 \%$ no valor da pegada hídrica. A pegada hídrica verde foi a mais representativa no valor total da pegada hídrica, $86,4 \%$ e $85,5 \%$ para os Grupos 1 e 2, respectivamente. Os animais do Grupo 1 tiveram um consumo médio de água de 83,3 $\mathrm{L}_{\text {animal }}{ }^{-}$ ${ }^{1} \mathrm{dia}^{-1}$ e os do Grupo 2, 80,4 $\mathrm{L}$ animal ${ }^{-1} \mathrm{dia}^{-1}$. O estudo demonstrou que o elevado teor de 
proteína bruta na dieta resulta em uma maior pegada hídrica e, portanto, menor eficiência hídrica. A prática nutricional proposta mostrou-se viável como ação mitigadora, tornando mais eficiente a relação de litros de água por litro de leite. Os resultados podem ser considerados como uma validação de uma prática de mitigação nutricional para melhorar a eficiência de uso da água e para o melhor manejo hídrico do complexo agroindustrial do leite.

Palavras-chave: azul, cinza, nitrogênio, teor de proteína, verde.

\section{INTRODUCTION}

One of the greatest present and future challenges for livestock is to remain a provider of quality food and conserve natural resources. This activity demands large volumes of water and has a high polluting potential as a point and no-point source. Therefore, a detailed understanding of livestock water uses and the impact of production practices on water efficiency can help the internalization of water management by the sector, reduce conflicts with society, and show how management practices promote water conservation.

Water is one of the most important factors on a dairy farm because it is essential for livestock consumption to support milk production. This dependence may lead to more active regulation and monitoring of water use, which puts a great amount of pressure, especially financially, on farmers (Robinson et al., 2016). Nowadays studies are estimating water consumption by ruminants, but the efforts are only based on direct water use (Murphy et al., 2014; Fischer et al., 2017; Legesse et al., 2017).

The physiological importance of water to dairy is well established. It is important when it comes to the health and well-being of the animal, but is a reductionist vision if the goal is the efficient use of water in the production system and the management of the natural resources. Investigations by Fischer et al. (2017) emphasize that the discussion about water consumption in livestock is from the perspective of production. However, this aspect must also be seen in the context of water demand by people, industry and services.

The water footprint approach provides information about water consumed and the impact of the product in the quantity and quality of water. Two internationally accepted concepts of water footprint have been developed; the water footprint concept (Hoekstra et al. (2017) and the Life Cycle Assessment (LCA). Very few studies have been performed to evaluate the impact of mitigation practices on the footprint value. The majority of the studies explored the impact of dairy production on freshwater resources of countries, basins, or production systems (Murphy et al., 2014; Palhares and Pezzopane, 2015). To evaluate the relationship between dairy production systems and water use, it is necessary to know the consumptive water used in the "feed production-dairy-manure management" chain and to identify the major factors affecting the water consumption for milk production (Lu et al., 2018). Legesse et al. (2017) reported that feed production/utilization, best water management practices, and animal production efficiency are strategies to increase the water efficiency of ruminant production.

Nutritional management is one of these strategies. By adopting better precision nutrition, it can improve water efficiency and reduce environmental impact. This will promote green, blue, and grey water efficiency. Palhares et al. (2018) showed that animal nutrition is a mitigation aspect to reduce the cost of water, natural resource consumption, and livestock polluting potential.

This study evaluated the impact of diet as a mitigation action to improve the water efficiency of lactating cows. Diet formulation for lactating cows considering the ideal crude protein content is not new to the science of animal nutrition. This investigation proposes a holistic view, considering the various aspects of dairy production systems, in this case animal nutrition, water consumption, water efficiency, and polluting potential. The innovation of this 
study is to give a water view to nutritional management, demonstrating that a nutritional practice routine in dairy production, besides all the productive and economic advantages, also has environmental advantages.

\section{MATERIALS AND METHODS}

The concept of the Water Footprint Standard (Hoekstra et al., 2011) was used to evaluate the water footprint of dairy milk in a cradle-to-farm gate perspective. This method was chosen considering the experience of the authors in its use and because it distinguishes between green, blue and grey water. Water footprint is a comprehensive indicator of freshwater resource appropriation, which goes beyond traditional restrictive measures of water withdrawal. The water footprint is defined as the total volume of fresh water that is consumed to produce a product. The consumptive water footprint is split into three categories: green, measuring consumption of rainwater; blue, measuring consumption of groundwater or surface water; and grey, measuring how much water is needed to assimilate polluting substances.

Water footprints were calculated from primary data related to direct and indirect water consumption, effluent nitrogen load, and feed and milk production.

\subsection{Systems data}

An intensive pasture dairy production system was considered in order to produce the raw milk. The lactating cows were milked twice daily at $0800 \mathrm{~h}$ and $1600 \mathrm{~h}$. The lactation period was 305 days. Raw milk production yield for Group 1 and Group 2 was 52,267 kg and 56,622 $\mathrm{kg}$, respectively. The average daily production per cow was $23.1 \mathrm{~L} \mathrm{day}^{-1}$ for Group 1 and 25.2 L day ${ }^{-1}$ for Group 2.

The diets of both experimental groups are presented in Table 1. Group 1 was fed with a diet containing $20 \%$ crude protein content in the diet of dry matter throughout the lactation. The crude protein content of Group 2 was determined according to milk production during the lactation period. Diets (roughage + concentrate) were given twice daily for each group.

Pasture and corn silage was cultivated on-farm and soya and maize were cultivated offfarm. Protein and fat content of milk varies depending on the type and age of animal, feed, and production management. International standards were determined for Fat Protein - Corrected Milk (FPCM) (FAO, 2013).

Table 1. Nutritional management and diets for the two experimental groups (average dry matter intake animal ${ }^{-1}$ day $\left.^{-1}\right)$.

\begin{tabular}{|c|c|c|c|c|c|c|c|c|c|c|c|c|}
\hline & \multicolumn{12}{|c|}{ Group 1} \\
\hline & \multicolumn{12}{|c|}{ Lactating Period (month) } \\
\hline Intake (kg) & 1 & 2 & 3 & 4 & 5 & 6 & 7 & 8 & 9 & 10 & 11 & 12 \\
\hline Total Dry matter & 25.3 & 21.1 & 24.5 & 21.6 & 21.7 & 22.9 & 20.2 & 20.1 & 20.1 & 20.1 & 20.1 & 20.1 \\
\hline Pasture & 7.8 & 2.5 & 4.5 & 4.5 & 4.5 & 4.5 & 4.8 & 9.5 & 9.5 & 9.5 & 9.5 & 9.5 \\
\hline Maize Silage & 5.9 & 7.0 & 8.4 & 5.6 & 6.6 & 7.8 & 4.8 & & & & & \\
\hline Concentrate* & 11.6 & 11.6 & 11.6 & 11.5 & 10.6 & 10.6 & 10.6 & 10.6 & 10.6 & 10.6 & 10.6 & 10.6 \\
\hline Soybean Meal & 3.5 & 3.5 & 3.5 & 3.5 & 3.6 & 3.6 & 3.6 & 3.6 & 3.6 & 3.6 & 3.6 & 3.6 \\
\hline Maize & 7.5 & 7.5 & 7.5 & 7.4 & 6.5 & 6.5 & 6.5 & 6.5 & 6.5 & 6.5 & 6.5 & 6.5 \\
\hline \multirow[t]{3}{*}{ Crude Protein $(\%)$} & 20 & 20 & 20 & 20 & 20 & 20 & 20 & 20 & 20 & 20 & 20 & 20 \\
\hline & \multicolumn{12}{|c|}{ Group 2} \\
\hline & \multicolumn{12}{|c|}{ Lactating Period (month) } \\
\hline Intake $(\mathrm{kg})$ & 1 & 2 & 3 & 4 & 5 & 6 & 7 & 8 & 9 & 10 & 11 & 12 \\
\hline Total Dry matter & 26.0 & 21.3 & 24.6 & 21.7 & 20.5 & 21.7 & 19.0 & 20.2 & 20.2 & 20.2 & 20.2 & 20.2 \\
\hline Pasture & 7.8 & 2.5 & 4.5 & 4.5 & 4.5 & 4.5 & 4.8 & 9.5 & 9.5 & 9.5 & 9.5 & 9.5 \\
\hline Maize Silage & 5.9 & 7.0 & 8.4 & 5.6 & 6.6 & 7.8 & 4.8 & & & & & \\
\hline Concentrate* & 12.3 & 11.8 & 11.7 & 11.6 & 9.4 & 9.4 & 9.4 & 10.7 & 10.7 & 10.7 & 10.7 & 10.7 \\
\hline Soybean Meal & 2.4 & 4.3 & 4.3 & 4.2 & 2.4 & 2.4 & 2.4 & 2.0 & 2.0 & 2.0 & 2.0 & 2.0 \\
\hline Maize & 9.2 & 6.8 & 6.7 & 6.7 & 6.5 & 6.5 & 6.5 & 8.2 & 8.2 & 8.2 & 8.2 & 8.2 \\
\hline Crude Protein (\%) & 23 & 23 & 23 & 17 & 17 & 17 & 17 & 17 & 17 & 14.5 & 14,5 & 14.5 \\
\hline
\end{tabular}

*Concentrate- is the sum of soybean meal, maize, and minerals. 


\subsection{Water footprint calculations}

The green water footprint is the sum of evapotranspiration water plus the water in the feed product. Each feedstuff produced or imported was considered to calculate the green water footprint. Feed produced at the farm considered field data and yields. Feed imported was taken from farm documents. The water volume of each feedstuff was reported from the dry matter content.

Green water footprint was calculated as Equation 1:

GreenW $=\frac{\sum_{p=1}^{n}(\text { ETc }+ \text { Product })}{\text { Production of Milkcorrected }}$

Green water footprint $\left(\right.$ GreenW) $\left(\mathrm{L} \mathrm{kg}^{-1}\right)$; ETc $[\mathrm{a}, \mathrm{s}]$ is the potential crop evapotranspiration of each feed ingredient $\mathrm{p}$ consumed by each experimental group $\left(\mathrm{L} \mathrm{kg}^{-1}\right)$; and Product is water content in feed ingredient $\mathrm{p}$ in each experimental group $\left(\mathrm{L} \mathrm{kg}^{-1}\right)$.

The potential crop evapotranspiration for pasture, corn silage, maize, and soya was calculated multiplying reference evapotranspiration (ETo) by based crop coefficient (Kc) (Allen et al., 1998). Reference evapotranspiration was derived from a climatic station installed at the farm using the Food and Agriculture Organization Penman-Monteith equation (Allen et al., 1998). Climatic parameters values were obtained monthly from the Agritempo database (AGRITEMPO, 2017).

The following productive conditions were used to calculate ETc: maize produced in Parana State, (Prudentopolis,) and soybean produced in Mato Grosso State (Rondonopolis,). It was considered that these crops were produced in a rainfed manner. To calculate Tanzania grass amounts, daily values of crop coefficient were used. Silage and grass were produced on the farm.

Soybean meal is the form that cows feed on. Technical Conversion Factors for Agricultural Commodities (FAO, 2013) were used to calculate the water quantity from evapotranspiration; considering the Brazilian condition, it is $77 \%$ meal and $23 \%$ oil.

Pasture irrigation, animal drinking, and water in the product were considered in the blue water calculation. Blue water footprint was calculated as Equation 2:

$$
B W=\frac{(\text { Wirr })+(\text { Wani })+(\text { Wprod })}{\text { Production of Milkcorrected }}
$$

Blue water footprint (BW) $\left(\mathrm{L} \mathrm{kg}^{-1}\right)$; Wirr is consumption of water to irrigate $\left(\mathrm{L} \mathrm{kg}^{-1}\right)$, Wani is water consumed by animals $\left(\mathrm{L} \mathrm{kg}^{-1}\right)$, and Wprod is water in milk, considering an average of $87 \%$ water per $\mathrm{kg}$ of milk (NEPA, 2011).

The drinking water intake of each lactating cow was recorded daily and measured by automatic water bin (Oliveira et al., 2018).

The irrigation water was evaluated considering the type of equipment. Irrigation characteristics were: 32 paddocks divided into seven irrigation sectors, each sector with twelve sprinklers with a flow rate of $0.45 \mathrm{~m}^{-3} \mathrm{~h}^{-1}$; nocturnal irrigation with two hours of irrigation per sector; irrigation efficiency of $85 \%$. Irrigation started on $06 / 09 / 2015$ and ended on 10/25/2015 (97 days).

The milking parlor comprised of a one-stage dairy shed effluent stabilization system. Effluent was considered water for cleaning and disinfection. Water meters were installed on the milking parlor to record effluent volume. To calculate the grey water footprint, nitrate was set as the pollutant under consideration. Grey water footprint was calculated as Equation 3:

$$
\text { GreyW }=\frac{[(\alpha \times(\text { Efu } \times \text { Cefu })] /(\text { Cmax }- \text { Cnat })}{\text { Production of Milkcorrected }}
$$


Grey water (GreyW) $\left(\mathrm{L} \mathrm{kg}^{-1}\right)$; $\alpha$ dimensionless factor, defined as the fraction of applied chemical substance reaching freshwater bodies; Eflu is volume of effluent (L); Ceflu is the nitrate concentration of the effluent $\left(23.6 \mathrm{mg} \mathrm{L}^{-1} \mathrm{~N}_{-\mathrm{NO}_{3}}-\right.$ Group 1 and $22.8 \mathrm{mg} \mathrm{L}^{-1} \mathrm{~N}_{-\mathrm{NO}_{3}-}$ Group 2) (Palhares and Pezzopane, 2015); Cmax is maximum acceptable concentration (mg $\mathrm{L}^{-1}$ ) with reference to CONAMA Resolution 357/2005 (10 $\left.\mathrm{mg} \mathrm{L}^{-1} \mathrm{~N}-\mathrm{NO}_{3}\right)$; and Cnat is natural concentration in a receiving water body $\left(\mathrm{mg} \mathrm{L}^{-1}\right)$, and was considered zero (CONAMA, 2005).

The average volume of effluent produced by each lactating cow during the study period was $39.8 \mathrm{~L}_{\text {animal }}{ }^{-1}$ day $^{-1}$. This value was multiplied by the number of cows in each group to get the volume of effluent.

\section{RESULTS AND DISCUSSION}

The total water footprints had a value of $502.4 \mathrm{~L} \mathrm{~kg}^{-1}$ FPCM for Group 1 and $451.2 \mathrm{~L} \mathrm{~kg}^{-1}$ FPCM for Group 2 (Table 2). This study demonstrated that high crude protein content in the diet, besides not producing more milk, caused a greater water footprint, therefore lower water efficiency of the product. It is emphasized that a higher protein concentration has a higher cost, which will also negatively impact the cost of production of the milk.

The manipulation of the crude protein content of the concentrate resulted in better water efficiency. Ran et al. (2016) indicate that feed quality, digestibility, and feed conversion efficiency impact livestock water productivity. Bosire et al. (2015) found diet composition can determine the magnitude of the water footprint of milk, because diet translates into better feed conversion and more efficient use of freshwater. White (2016) showed that management to reduce water consumption of dairy cattle improves the use of protein and energy. Palhares et al. (2017) demonstrated that diet formulation is a tool to improve the water efficiency of animal products.

Table 2. Water footprints by experimental group.

\begin{tabular}{lcccc}
\hline Waters & \multicolumn{2}{c}{ Group 1 } & \multicolumn{2}{c}{ Group 2 } \\
\hline Green $\left(\mathrm{L} \mathrm{kg}^{-1}\right.$ FPCM) & 434.0 & $(86,4 \%)$ & 386.0 & $(85,5 \%)$ \\
Blue $\left(\mathrm{L} \mathrm{kg}^{-1}\right.$ FPCM) & 67.7 & $(13,5 \%)$ & 64.6 & $(14,4 \%)$ \\
Gray $\left(\mathrm{L} \mathrm{kg}^{-1}\right.$ FPCM) & 0.7 & $(0,14 \%)$ & 0.6 & $(0,13 \%)$ \\
\hline Total Footprint $\left(\mathrm{L} \mathrm{kg}{ }^{-1}\right.$ FPCM) & 502.4 & & 451.2 & \\
\hline
\end{tabular}

The green water footprint was the most representative, $86.4 \%$ and $85.5 \%$ for Groups 1 and 2 , respectively, in the water footprint value. Bai et al. (2018) found that indirect water footprint accounting for more than $92 \%$ of dairy farm water footprint. Noya et al. (2018) showed that feed/fodder production contributed $99 \%$ of the water footprint of milk while the dairy farm stage has a minor influence. These results showed the importance of the indirect water consumption instead of the minor influence of the direct water requirements. The water footprint of animal and plant products involves biological systems that have different phases of development, have specific nutrient requirements and are influenced by different climatic and management aspects. Therefore, there is a need for all these aspects to be evaluated together, as well as their interrelations, in order to achieve results of significant impact.

The diet with the adjusted protein provided a reduction of $11 \%$ in the green footprint value. Owusu-Sekyere et al. (2017) verified that dairy diets with high protein concentrates had the highest water footprint. According to Mekonnen and Hoekstra (2014), green water footprint for milk in pasture systems is $1.087 \mathrm{~L} \mathrm{~kg}^{-1}$ of milk. This represents more than double the values found in this study. The difference can be the result of the type of diet considered in the studies, not as a comparable functional unit, the geographical and temporal location of crop cultivation, and milk production. De Léis et al. (2015) point that the productive factors that most impact 
the value of the green water consumption and footprint are the animals' diet, dry-matter intake, and agricultural productivity. Zhuo et al. (2016) propose choosing crops that have more nutritional value and consume less water.

The water footprint of soybean was $4,304 \mathrm{~m}^{3} \mathrm{ha}^{-1}$ and for maize it was $3,246 \mathrm{~m}^{3} \mathrm{ha}^{-1}$. As the adjusted diet presented a total lower demand of soybean meal, the green water consumption in Group 2 was lower. This is characteristic of the tropical regions and the major Brazilian grain-producing regions due to the fact that the rainfall satisfies the crops' water demands. The maize WF quantified by other authors was 1,222 m3 ton-1 (Mekonnen and Hoekstra, 2010), $910 \mathrm{~m} 3$ ton-1 (Wang et al., 2014), $900 \mathrm{~m} 3$ ton-1 (Chapagain and Hoekstra, 2004), $868 \mathrm{~m} 3$ ton1 (Huang et al., 2014), and $750 \mathrm{~m} 3$ ton-1 (Williams and Al-Hmoud, 2015).

To calculate the green water consumption of the pasture, only the portion of pasture ingested daily by the animals was recorded. Thus, the total green water consumed was $403 \mathrm{~m}^{3}$. The quantification of green water volume in cattle production systems that include grazing basically can have two interpretations: considering only the portion of grass that was ingested by the animal or the total evapotranspiration of the grazing area. In this study we chose to calculate considering only the amount of grass ingested by the animals. If the total area of the rotational grazing system ( $1.7 \mathrm{ha}$ ) were considered, the green water consumption from pasture would be $95 \%$ higher. There is still no methodological standardization for the calculation of the green water consumed from grazing systems. It is known that in a rotational grazing system the entire area contributes to the production of the products and that this system provides reduced environmental services.

The silage consumed by Group 1 represented the volume of $1,448 \mathrm{~m}^{3}$ of green water and, for Group 2, was $1,478 \mathrm{~m}^{3}$. If pasture irrigation had not been used in the dry period, the animals would need to be fully supplemented with maize silage. This situation means that green water consumption of Group 1 would increase by $6.8 \%$ and that of Group 2 by $7.7 \%$. Consequently, blue water consumption would reduce by $72.8 \%$ because no irrigation would be used.

The blue water footprint of Group 1 was $67.7 \mathrm{~L} \mathrm{~kg}^{-1}$ FPCM, and for Group $264.6 \mathrm{~L} \mathrm{~kg}^{-1}$ FPCM. Mekonnen and Hoekstra (2014) estimated 56 L kg-1 FPCM and Huang et al. (2014) estimated $69 \mathrm{~L} \mathrm{~kg}^{-1}$ FPCM. Palhares and Pezzopane (2015) calculated the same production system evaluated in this study as $75 \mathrm{~L} \mathrm{~kg}^{-1}$ FPCM, but without nutritional management intervention.

In Group 1, the composition of the blue water footprint was $93.3 \%\left(63.2 \mathrm{~L} \mathrm{~kg}^{-1}\right.$ FPCM) irrigation water, $5.4 \%\left(3.6 \mathrm{~L} \mathrm{~kg}^{-1}\right.$ FPCM$)$ drinking water, and $1.3 \%\left(0.87 \mathrm{~L} \mathrm{~kg}^{-1} \mathrm{FPCM}\right)$ water in the product. For Group 2, these percentages were $93.3 \%\left(60.3 \mathrm{~L} \mathrm{~kg}^{-1} \mathrm{FPCM}\right)$ irrigation water, $5.3 \%\left(3.4 \mathrm{~L} \mathrm{~kg}^{-1} \mathrm{FPCM}\right)$ drinking water, and $1.3 \%\left(0.87 \mathrm{~L} \mathrm{~kg}^{-1} \mathrm{FPCM}\right)$ water in the product. Irrigation represented the highest consumption of blue water, totaling $6,297 \mathrm{~m}^{3}$. If irrigation were not used, the value of the blue water footprint would be reduced by 15 times. Henderson et al. (2017) calculated the national average blue water consumption for the US associated with milk production. It was $210 \mathrm{~L} \mathrm{~kg} \mathrm{milk}^{-1}$ and is dominated by feed irrigation. Studies that calculated the dairy blue water footprint without considering irrigation found values between 1.2 to $9.7 \mathrm{~L} \mathrm{~kg}^{-1}$ FPCM (Murphy et al., 2014).

Irrigation is a practice used to maintain pasture production at the beginning of the dry season in tropical regions because it means reduced feed costs due to the lower need to buy concentrated feed. But the practice should be based on best practices and scheduling does not mean inefficient water use. As the cost of water is zero or insignificant compared to the cost of concentrated feed, farmers use irrigation without worrying about the volume of water consumed if they are in a region without water scarcity problems.

The animals in Group 1 had a mean total drinking water consumption of $83.3 \mathrm{~L}_{\text {animal }}{ }^{-1}$ day $^{-1}$ and those of Group 2, 80.4 $\mathrm{L}_{\text {animal }}{ }^{-1}$ day $^{-1}$. The average daily water consumption per Holstein lactating cows was $114 \mathrm{~L}_{\text {animal }}{ }^{-1}$ day $^{-1}$ (Le Riche et al., 2017) and 78.4 L animal ${ }^{-1}$ 
day $^{-1}$ (Appuhamy et al., 2016). Considering a lactation period, the animals of Group 1 drank $165.9 \mathrm{~m}^{3}$ and those of Group 2,165 $\mathrm{m}^{3}$. The difference is 900 liters. Chouchane et al. (2015) and Owusu-Sekyere (2016) noted that blue water use is associated with production costs.

In Group 1, the drinking water intake per kg of milk produced was $3.6 \mathrm{~L} \mathrm{~kg}^{-1} \mathrm{FPCM}$ and for Group 2, 3.4 $\mathrm{L} \mathrm{kg}^{-1}$ FPCM. The adjustment of the protein content of the diet contributed to a reduced consumption of drinking water and positively impacted the relation between water consumption by the quantity of product. The lack of routine measuring of water consumption in dairy farms is a great challenge to have more precise calculations of blue water consumption and footprint. Considering the various consumptions of blue water in the dairy system, drinking water consumption by lactating cows is one of the largest. Therefore, the use of water meters is essential for advancements in the water management of dairy production.

Group 1 presented a higher value of grey water footprint. The results demonstrate that excessive crude protein content in the diet results in a higher consumption of water from the environment to assimilate the pollutant loads generated by the production system. By integrating nutrient-use efficiency (adjustable protein) with the calculation of the grey water footprint, it was possible to identify the relationship between the type of diet, the polluting potential, and the value of the footprint. The evaluation by White (2016) of the environmental benefits of animal-nutrition research demonstrated that improved protein efficiency greatly reduced the cost of achieving targeted reductions in water use in dairy production. Animals from the groups presented different nitrogen-use efficiencies, and consequently had different concentrations of it in their effluents. Therefore, the diet with adjustable protein produced an effluent with a lower nitrogen load, requiring less water to dilute the effluent. In this way, the study promoted the advantages of the relationships between the grey water footprint from diffuse sources and the nutritional management of the animal systems. The connection between the livestock productive aspects is essential. For example, diets with low green and/or blue footprints may result in high grey footprint values, because if the digestibility of the nutrients of the diet is poor, they will be eliminated as wastes, which will affect the volume of greywater.

\section{CONCLUSIONS}

The results demonstrated that the manipulation of the crude protein content of the lactating cow diet improved milk water efficiency in all water footprint dimensions. Footprint values showed that the nutritional approach can be a general recommendation across all regions and production systems to increase water efficiency and reduce the conflicts of resource availability. Therefore, the proposed nutritional practice proved viable as a water-mitigating action, making the ratio of liters of water per liter of milk more advantageous. The results reinforce the fact that the use of best practices in animal nutrition can also have positive impacts on several aspects of the dairy system.

The results of this study could be considered a validation of a nutritional mitigation practice to improve water efficiency and could be used as best management by farmers, the dairy industry and governments as a water-saving strategy from an environment and economic costbenefit point of view. The study also contributes to the provision of benchmarks regarding mitigation actions that can be used to improve dairy water-use efficiency. Future studies should continue to explore the relationship between practices and technologies in animal nutrition and water efficiency, as well as other productive aspects such as genetics, the type of production system and the use and reuse of water and effluents in productive management.

\section{ACKNOWLEDGES}

To the Brazilian Agricultural Research Company - Embrapa Southeast Livestock and the researchers Teresa Cristina Alves and Andre Luiz M. Novo by the supplying in the study 
delineation. This study was supported by The National Council for Scientific and Technological Development (CNPq) (Proc. 404243/2013-4).

\section{REFERENCES}

AGRITEMPO. Agrometeorological Monitoring System: Southeast Region stations. Available at: http://www.agritempo.gov.br/agritempo/redeEstacoes.jsp. Access: 2017.

ALLEN, R. G.; PEREIRA, L. S.; RAES, D.; SMITH, M. Crop evapotranspiration: guidelines for computing crop water requirements. Rome: FAO, 1998.

APPUHAMY, J. A. D. R. N. et al. Prediction of drinking water intake by dairy cows. Journal of Dairy Science, v. 99, n. 9, p. 7191-7205, 2016. http://dx.doi.org/10.3168/jds.201610950

BAI, X. et al. Comprehensive water footprint assessment of the dairy industry chain based on ISO 14046: A case study in China. Resources, Conservation and Recycling, v. 132, p. 369-375, 2018. http://dx.doi.org/10.1016/j.resconrec.2017.07.021

BOSIRE, C. K.; OGUTU, J. O.; SAID, M.Y. et al. Trends and spatial variation in water and land footprints of meat and milk production systems in Kenya. Agriculture, Ecosystems and Environment, v. 205, p. 36-47, 2015. http://dx.doi.org/10.1016/j.agee.2015.02.015

CHOUCHANE, H.; HOEKSTRA, A. Y.; KROL, M. S. et al. The water footprint of Tunisia from an economic perspective. Ecological Indicators, v. 52, p. 311-319, 2015. https://dx.doi.org/10.1016/j.ecolind.2014.12.015

CONAMA (Brasil). Resolução n 357 de 17 de março de 2005. Dispõe sobre a classificação dos corpos de água e diretrizes ambientais para o seu enquadramento, bem como estabelece as condições e padrões de lançamento de efluentes, e dá outras providências. Diário Oficial [da] União: seção 1, Brasília, DF, n. 053, p. 58-63, 18 mar. 2005.

DE LÉIS, C. M. et al. Carbon footprint of milk production in Brazil: a comparative case study. The International Journal of Life Cycle Assessment, v. 20, n. 1, p. 46-60, 2015. http://dx.doi.org/10.1007/s11367-014-0813-3

FAO. Technical conversion factor for agriculture commodities. 2013. Available at: http://www.fao.org/fileadmin/templates/ess/documents/methodology/tcf.pdf. Access: 2017.

FISCHER, A. et al. Studies on drinking water intake of fallow deer, sheep and mouflon under semi-natural pasture conditions. Grassland Science, v. 63, n. 1, p. 46-53, 2017. http://dx.doi.org/10.1111/grs.12149

HENDERSON, A. D.; ASSELIN-BALENÇON, A. C.; HELLER, M. et al. Spatial variability and uncertainty of water use impacts from U.S. feed and milk production. $\begin{array}{llllllll}\text { Environmental Science } \quad \& \quad \text { Technology, } & \text { v. } & \text { 51, } & \text { n. } & 4,\end{array}$ http://dx.doi.org/10.1021/acs.est.6b04713

HOEKSTRA, A. Y. Water Footprint Assessment: Evolvement of a New Research Field. Water

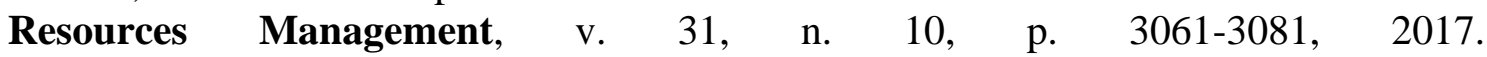
http://dx.doi.org/10.1007/s11269-017-1618-5

HOEKSTRA, A. Y.; CHAPAGAin, A. K.; ALDAYA, M. M.; MEKONNEN, M. M. The Water Footprint Assessment Manual: Setting the Global Standard. London: Earthscan, 2011.203p. 
HUANG, J. et al. Water availability footprint of milk and milk products from large-scale dairy production systems in Northeast China. Journal of Cleaner Production, v. 79, p. 91-97, 2014. https://doi.org/10.1016/j.jclepro.2014.05.043

LE RICHE, E. et al. Water Use and Conservation on a Free-Stall Dairy Farm. Water, v. 9, n. 12, p. 977-990, 2017. http://dx.doi.org/10.3390/w9120977

LEGESSE, G. et al. Water use intensity of Canadian beef production in 1981 as compared to 2011. Science of The Total Environment, v. 619-620, p.1030-1039, 2018. http://dx.doi.org/10.1016/j.scitotenv.2017.11.194

LEGESSE, G. et al. Board-invited review: Quantifying water use in ruminant production1.

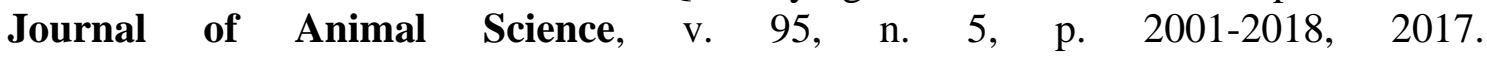
http://dx.doi.org/10.2527/jas.2017.1439

LU, Y. et al. Components of feed affecting water footprint of feedlot dairy farm systems in Northern China. Journal of Cleaner Production, v. 183, p. 208-219, 2018. http://dx.doi.org/10.1016/j.jclepro.2018.02.165

MEKONNEN, M. M.; HOEKSTRA, A. Y. Water footprint benchmarks for crop production: A first global assessment. Ecological Indicators, v. 46, p. 214-223, 2014. http://dx.doi.org/10.1016/j.ecolind.2014.06.013

MURPHY, E.; UPTON, J.; HOLDEN, N. M.; CURRAN, T. P. Direct water use on irish dairy farms. In: BIOSYSTEMS ENGINEERING RESEARCH SEMINAR, 19., 2014, Dublin. Proceedings[...] Dublin: School of Biosystems Engineering at University College Dublin, 2014. p.146-148.

NEPA. Tabela Brasileira de Composição de Alimentos. 4. ed. Campinas: NEPA-UNICAMP, 2011. 161 p. Available at: http://www.nepa.unicamp.br/taco/contar/taco_4_edicao_ampliada_e_revisada.pdf. Access: 2017.

NOYA, I. et al. Environmental and water sustainability of milk production in Northeast Spain. Science of The Total Environment, v. 616-617, p. 1317-1329, 2018. http://dx.doi.org/10.1016/j.scitotenv.2017.10.186

OLIVEIRA, B. R. et al. Validation of a system for monitoring individual feeding and drinking behaviour and intake in young cattle. Animal, v. 12, n. 3, p. 634-639, 2018. http://dx.doi.org/10.1017/s1751731117002002

PALHARES, J. C. P.; AFONSO, E. R.; GAMEIRO, A. H. Reducing the water cost in livestock with adoption of best practices. Environment, Development and Sustainability, v. 21, n. 4, p. 2013-2023, 2018. http://dx.doi.org/10.1007/s10668-018-0117-z

PALHARES, J. C. P.; MORELLI, M.; COSTA JUNIOR, C. Impact of roughage-concentrate ratio on the water footprints of beef feedlots. Agricultural Systems, v. 155, p.126-135, 2017. http://dx.doi.org/10.1016/j.agsy.2017.04.009

PALHARES, J. C. P.; PEZZOPANE, J. R. M. Water footprint accounting and scarcity indicators of conventional and organic dairy production systems. Journal Of Cleaner Production, v. 93, p. 299-307, 2015. http://dx.doi.org/10.1016/j.jclepro.2015.01.035

RAN, Y. et al. Assessing water resource use in livestock production: A review of methods. Livestock Science, v. 187, p. 68-79, 2016. http://dx.doi.org/10.1016/j.livsci.2016.02.012 
ROBINSON, A. D. et al. Usage and attitudes of water conservation on Ontario dairy farms.

The Professional Animal Scientist, v. 32, n. 2, p. 236-242, 2016. http://dx.doi.org/10.15232/pas.2015-01468

OWUSU-SEKYERE, E.; SCHEEPERS, M. E.; JORDAAN, H. Economic Water Productivities Along the Dairy Value Chain in South Africa: Implications for Sustainable and Economically EfficientWater-use Policies in the Dairy Industry. Ecological Economics, v. 134, p. 22-28, 2017. http://dx.doi.org/10.1016/j.ecolecon.2016.12.020

OWUSU-SEKYERE, E.; SCHEEPERS, M.E.; JORDAAN, H. 2016. Water Footprint of Milk Produced and Processed in South Africa: Implications for Policy-Makers and Stakeholders along the Dairy Value Chain. Water, v. 8, p. 322, 2016. http://dx.doi.org/10.3390/w8080322

WANG, Y.; CAO, X.; WU, P.; ZHAO, X. Water Footprint of Grain Product in Irrigated Farmland of China. Water Resource Management, v. 28, p. 2213-2227, 2014. https://dx.doi.org/10.1007/s11269-014-0607-1

WHITE, R. R. Increasing energy and protein use efficiency improves opportunities to decrease land use, water use, and greenhouse gas emissions from dairy production. Agricultural Systems, v. 146, p. 20-29, 2016. http://dx.doi.org/10.1016/j.agsy.2016.03.013

WILLIAMS, R. B.; AL-HMOUD, R. Virtual Water on the Southern High Plains of Texas: The Case of a Nonrenewable Blue Water Resource. Natural Resources, v. 6, p. 27-36, 2015. http://dx.doi.org/10.4236/nr.2015.61004

ZHUO, L. et al. Inter- and intra-annual variation of water footprint of crops and blue water scarcity in the Yellow River basin (1961-2009). Advances in Water Resources, v. 87, p. 29-41, 2016. http://dx.doi.org/10.1016/j.advwatres.2015.11.002 